\title{
SISTEM INFORMASI PEMINJAMAN DAN PENGEMBALIAN BUKU PADA PERPUSTAKAAN NAGARI SANING BAKAR BERBASIS WEB
}

\author{
Edni Wulandari \\ Universitas Mahaputra Muhammad Yamin \\ Email: wulandariedni@yahoo.com
}

(Naskah masuk: 20 Juni 2020, diterima untuk diterbitkan: 27 Juni 2020)

\begin{abstract}
Abstrak
Perpustakaan ialah suatu ruangan yang berisi berbagai macam koleksi bahan cetak maupun non tercetak yang bermanfaat bagi pengguna, sebagai sumber untuk mencari informasi dan ilmu pengetahuan. Beberapa perpustakaan telah ada yang menggunakan teknologi komputer untuk memudahkan pekerjaan para petugas dalam hal pengimputan data perpustakaan. Akan tetapi Perpustakaan Nagari Saning Bakar masih menggunakan cara manual dalam proses pencatatan sistem informasi. Oleh karena itu dibangunlah sebuah Sistem Informasi Peminjaman Dan Pengembalian Buku Pada Perpustakaan Nagari Saning Bakar Berbasi Web. Perancangan sistem informasi perpustakaan berbasis web, menggunakan program editor Macromedia Dreamweaver8 dan ditunjang dengan database MySQL. Dimana dengan adanya sistem informasi peminjaman dan pengembalian buku pada perpustakaan ini dapat membantu dan mempermudah pekerjaan para petugas dalam pembuatan laporan data buku baru masuk, buku yang dipinjam, buku yang telah dikembalikan, dan pemasukan uang akan denda keterlambatan pengembalian buku. Dengan pendataan secara komputerisasi maka menghasilkan laporan-laporan yang lebih akurat tanpa adanya kesalahan.
\end{abstract}

Kata kunci: Sistem Informasi Perpustakaan, Database MySQL, Web

\section{WEB-BASED BORROWING BOOK LENDING AND RETURN INFORMATION SYSTEM ON NAGARI SANING BAKAR LIBRARY}

\begin{abstract}
A library is a room that contains a variety of collections of printed and non-printed materials that are useful for users, as a source for finding information and knowledge. Some libraries already exist that use computer technology to facilitate the work of officers in library data collection. However, the Nagari Saning Bakar Library still uses manual methods in the process of recording information systems. Therefore, a Loan and Book Return Information System was built at the Nagari Saning Bakar Library based on Web. Web-based library information system design, using the Macromedia Dreamweaver8 editor program and supported by a MySQL database. Where with the information system of borrowing and returning books in this library can help and facilitate the work of the officers in making reports on incoming new books, borrowed books, books that have been returned, and cash income will be fined late return of books. With computerized data collection it produces more accurate reports without errors.
\end{abstract}

Keywords: Library Information System, MySQL Database, Web

\section{PENDAHULUAN}

Perpustakaan merupakan suatu ruangan/ bangunan yang digunakan untuk mengumpulkan, menyimpan, mengelola dan mengatur koleksi bahan pustaka secara sistematis untuk digunakan sebagai sumber informasi sekaligus sebagai sarana belajar yang menyenangkan.

Perpustakaan Nagari Saning Bakar merupakan perpustakaan umum, dimana semua lapisan masyarakat gemar membaca buku. Perpustakaan Nagari Saning Bakar menyediakan berbagai macam jenis sumber bacaan bagi masyarakat dan pustakawan. Akan tetapi dengan semakin berkembangnya teknologi dan jaringan informasi yang tanpa batas serta pemanfaatan perangkat komputer sebagai media untuk memproses data dan mencari informasi. Hal tersebut dapat mengurangi minat masyarakat dan pustakawan untuk mengunjungi perpustakaan, karena sistem informasi perpustakaan masih semi terkomputerisasi. Dimana pada saat pustakawan ingin membaca dan meminjam buku, pustakawan harus mencari buku tersebut terlebih dahulu dan pustakawan tidak mengetahui apakah buku yang ingin dibaca dan dipinjam tersedia pada saat itu. 
Oleh karena itu, dibangunlah sebuah Sistem Informasi Peminjaman Dan Pengembalian Buku Pada Perpustakaan Nagari Saning Bakar Berbasis Web, dengan menggunakan Database MySQL dan dibantu dengan program editor Macromedia Dreamweaver8. Dimana dengan adanya Sistem Informasi Peminjaman dan Pengembalian Buku ini dapat mempermudah pustakawan dalam mencari informasi buku yang ingin dibaca dan dipinjam, serta dapat membantu dan mempermudah pekerjaan para petugas dalam pembuatan laporan data buku yang dipinjam dan buku yang telah dikembalikan. Dengan pendataan secara komputerisasi maka dapat menghasilkan laporan-laporan yang lebih akurat tanpa adanya kesalahan.

\section{LANDASAN TEORI}

\subsection{Sistem Informasi}

Sistem informasi adalah kumpulan data dari prosedur-prosedur yang berhubungan satu dengan yang lainnya membentuk suatu kesatuan, untuk mencapai tujuan tertentu yang berguna atau lebih berarti bagi penerimanya.

Menurut Khana Wijaya (2019:53) Sistem informasi adalah data yang diolah menjadi bentuk yang lebih berguna dan lebih berarti bagi penerimanya. Data adalah fakta atau gambaran berbentuk mentah, data mewakili pengukuran atau pengamatan obyek-obyek kejadian kemudian data diolah menjadi informasi. Proses transformasi dari data ke informasi inilah yang disebut dengan sistem informasi.

\subsection{Perpustakaan}

Menurut Yusuf (2007) dalam Agus Irawan dan Ahmad Najiullah Perpustakaan adalah suatu tempat yang didalamnya terdapat kegiatan penghimpunan, pengelolaan, dan penyebarluasan (pelayanan) segala macam informasi, baik yang tercetak maupun yang terekam dalam berbagai media seperti buku, majalah, surat kabar, film, kaset, tape recorder, video.

Sedangkan menurut Darmono (2001:3) dalam Herman Adi Riyanto, dkk (2016:2) , pengertian Perpustakaan adalah salah satu unit kerja yang berupa tempat untuk mengumpulkan, menyimpan, mengelola dan mengatur koleksi bahan pustaka secara sistematis untuk digunakan oleh pemakai sebagai sumber informasi sekaligus sebagai sarana belajar yang menyenangkan.

\subsection{PHP}

Menurut Sunarfrihantono (2002) dalam Andi Rahman Putera dan Malik Ibrahim (2018:58-59) PHP adalah bahasa server-side scripting yang menyatu dengan HTML untuk membuat halaman web yang dinamis. Maksud dari server-side scripting adalah sintaks dan perintah-perintah yang diberikan akan sepenuhnya akan dijalankan diserver tetapi disertakan pada dokumen HTML.

\subsection{Database MySQL}

Menurut Sunarfrihantono (2002) dalam Andi Rahman Putera dan Malik Ibrahim (2018:59) MySQL adalah multiuser database yang menggunakan bahasa Structured Query Language (SQL). MySQL dalam operasi client server melibatkan server daemon MySQL disisi server dan berbagai macam program serta library yang berjalan disisi client. MySQL mampu mengangani data yang cuku besar.

\subsection{Web}

Menurut Yadi Utama (2011:360) Website atau situs dapat diartikan sebagai kumpulan halaman halaman yang digunakan untuk menampilkan informasi, teks, gambar diam atau bergerak, animasi, suara, dan atau gabungan dari semuanya itu, baik yang bersifat statis maupun dinamis yang membentuk satu rangkaian bangunan yang saling berkait dimana masing-masing dihubungkan dengan jaringan jaringan halaman (hyperlink).

\section{METODOLOGI PENELITIAN}

\subsection{Lokasi dan Waktu Penelitian}

Penelitian dilakukan pada Perpustakaan Nagari Saning Bakar, yang beralamat di Jorong Balai Batingkah Nagari Saning Bakar Kecamatan X Koto Singkarak Kabupaten Solok. Penelitian berlangsung selama 3 (tiga) bulan.

\subsection{Metode Pengumpulan Data}

Metode pengumpulan data tentang jenis dan sumber data serta teknik pengumpulan data yang digunakan selama penelitian adalah :

\section{Wawancara}

Pengumpulan data Peminjaman Dan Pengembalian Buku pada Perpustakaan Nagari Saning Bakar ditanyakan langsung kepada Kepala Pustaka Nagari Saning Bakar, sehingga mendapatkan data yang lebih objektif dan memperoleh jawaban yang lebih mendalam.

\section{Studi Kepustakaan}

Mengacu kepada jurnal, buku dan e-book yang sesuai dengan judul yang diangkat.

\section{Analisis}

Sistem yang digunakan pada Peminjaman Dan Pengembalian Buku pada Perpustakaan Nagari Saning Bakar awalnya semi terkomputerisasi, maka dari itu dibutuhkan sebuah Sistem Informasi Berbasis Web untuk mempermudah dalam pengolahan dan penyajian data Peminjaman Dan Pengembalian Buku pada Perpustakaan Nagari Saning Bakar.

\section{Perancangan}

Untuk merancang Sistem Informasi Peminjaman dan Pengembalian Buku berbasis Web pada perpustakaan Nagari Saning Bakar menggunakan Aliran Sistem Informasi (ASI) dan Data Flow Diagram (DFD).

5. Program

Untuk Merancang Sistem Informasi Peminjaman dan Pengembalian Buku Berbasis Web pada Perpustakaan Nagari Saning Bakar, digunakan 
Bahasa Pemrograman Web editor program Macromedia Dreamweaver8 dan ditunjang oleh $M y S Q L$ untuk pembuatan database.

\section{Uji Coba}

Kegiatan uji coba dilakukan untuk melihat hasil perancangan dan pemrograman Sistem Informasi Berbasis Web.

\subsection{Metoda Analisa}

Model pengembangan sistem yang digunakan yaitu Sistem Development Life Cycle (SDLC) yang terdiri dari 7 subsiklus, seperti pada gambar berikut ini :

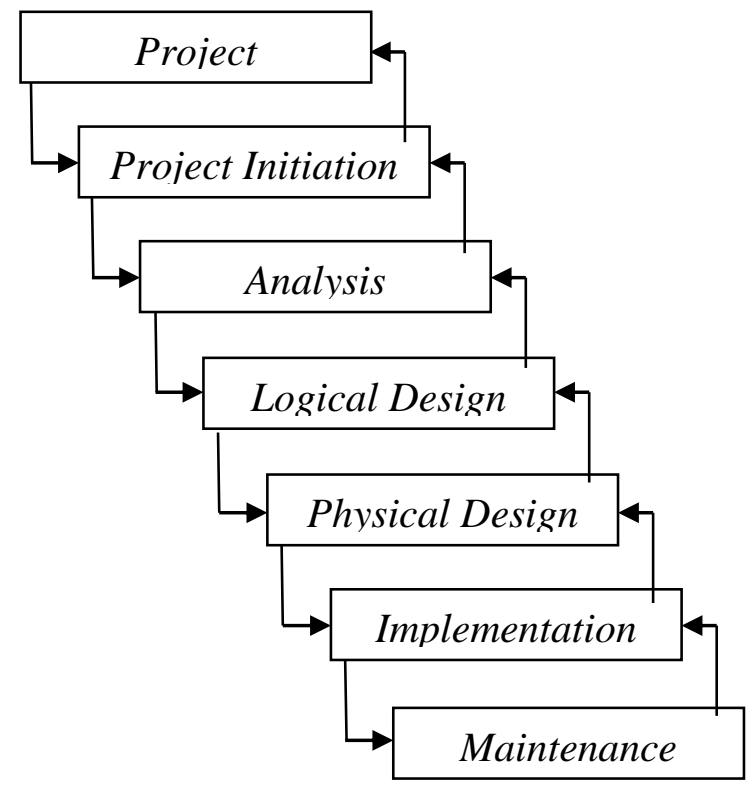

Gambar 1. Diagram SDLC

Output atau produk yang dihasilkan ditiap phase SDLC

1. Project Identification \& Selection, menghasilkan :

Perencanaan Sistem, yaitu menentukan prioritas sistem dan proyek, arsitektur dari data, jaringan, hardware, dan manajemen dari sistem. Pada tahap ini akan dilakukan indentifikasi terhadap permasalahan yang ada sehubungan dengan tujuan pembangunan Sistem Informasi Peminjaman Dan Pengembalian Buku Pada Perpustakaan Nagari Saning Bakar Berbasis Web. Untuk kegiatan ini diperlukan waktu 1 bulan.

2. Project Initiation \& Planning, menghasilkan :

Langkah terperinci atau rencana kerja untuk proyek, spesifikasi dari ruang lingkup penelitian dan syarat/bentuk sistem (high-level), tugas untuk anggota team dan sumber daya lainnya, sistem perundangan pertimbangan. Dalam tahap ini dilakukan akan ditentukan ruang lingkup dan batasan penelitian, perencanaan sistem serta rencana pengalokasian sumber daya yang dimiliki untuk melaksanakan penelitian ini. Kegiatan ini akan memakan waktu sekitar 2 bulan dan dimulai di bulan kedua penelitian.

3. Analysis, menghasilkan :
Kegiatan yang diprediksi akan memakan waktu kurang lebih 2 bulan ini bertujuan melakukan penjabaran mengenai sistem yang ada termasuk masalah atau peluang yang ada yang direkomendasi untuk di perbaiki/diatasi, ditingkatkan, atau mengganti sistem yang ada, uraian mengenai sistem pilihan dan sistem perundangan /pertimbangan untuk sistem yang terpilih.

4. Physical design, menghasilkan :

Pada bulan ke dua penelitian, tahapan ini lebih bersifat teknis, spesifikasi terperinci dari semua element sistem (program, file-file, jaringan, sistem software, dll). Rencana untuk teknologi baru, tahap ini akan memberikan hasil berupa rancangan fisik berupa jenis software yang akan digunakan, tools yang akan digunakan untuk implementasi sistem serta spesifikasi hardware yang dibutuhkan. Sehingga sistem yang diinginkan bisa direalisasikan. Pelaksanaan kegiatan ini sekitar 2 bulan.

5. Implementation, menghasilkan :

Code/listing program, dokumentasi, prosedur pelatihan, dan support/dukungan yang dapat diberikan. Tahap ini akan memberikan output berupa sistem yang diinginkan yaitu sebuah system informasi yang mampu membantu dalam proses peminjaman dan pengembalian buku, sehingga hasil yang didapat dalam proses peminjaman dan pengembalian buku akurat dan tentunya lebih efektif. Kegiatan atau tahapan ini akan memakan waktu kurang lebih 2 bulan.

6. Maintenance, menghasilkan :

Software versi terbaru atau dengan pembaruan untuk dokumentasi, pelatihan, support /dukungan terhadap hasil penelitian.

\section{HASIL DAN PEMBAHASAN}

\section{1 .Analisa Sistem Yang Sedang Berjalan}

\section{Identification dan selection :}

Analisa sistem ini bertujuan untuk merancang sistem yang baru, merancang perubahan-perubahan dalam pengambilan keputusan serta mengetahui bagaimana sistem pengolahannya dan mengetahui masalah yang ditemukan dalam proses pengambilan keputusan. analisa sistem merupakan penelusuran dari sistem yang sedang berjalan, sehingga memudahkan analsis dalam pendefenisian permasalahan yang timbul dalam instansi atau lembaga untuk membuat sistem baru. Sistem lama peminjaman dan pengembalian buku pada Perpustakaan Nagari Saning Bakar masih manual, dimana petugas Perpustakaan Nagari Saning pada saat proses pencatatan peminjaman buku masih menggunakan buku besar dalam proses pencatatannya, dan juga pada saat pengembalian buku, petugas juga menggunakan cara yang sama, sehingga sering terjadinya kesalahan dalam pencatatan kode buku, nama, buku, penerbit dan lain sebagiannya. Begitu juga 
dengan proses penghitungan denda bagi yang telat mengembalikan buku juga dilakukan secara manual, sehingga terjadi kesalahan dalam mengitung denda.

\section{Kelemahan}

Berdasarkan analisa yang telah dilakukan terlihat bahwa dalam sistem yang lama terdapat beberapa kelemahan yaitu :

1. Proses pencatatan peminjaman dan pengembalian buku masil dilakukan secara manual.

2. Sering terjadi kesalahan pada saat proses penghitungan denda.

\section{Initiation and Planning :}

Untuk mengatasi permasalahan yang timbul dalam proses peminjaman dan pengembalian buku pada Perpustakaan Nagari Saning Bakar, maka dilakukan suatu bentuk pengembangan sistem pengolahan data peminjaman dan pengembalian buku yang didukung oleh sistem informasi berbasis Web dengan alat bantu komputer, sehingga menghasilkan data yang lebih akurat, tepat dan sesuai dengan yang diinginkan.

\section{Analyze (Analisa):}

Keunggulan dari sistem informasi peminjaman dan pengembalian buku pada Perpustakaan Nagari Saning Bakar ini ialah dapat mengurangi kesalahan dari ketidak akuratannya data peminjaman dan pengembalian buku. Dengan adanya sistem informasi peminjaman dan pengembalian buku pada Perpustakaan Nagari Saning Bakar berbasis web ini, dapat menghasilkan data yang akurat dan terkomputerisasi sehingga mengurangi kesalahan manusia (human error).

\subsection{Design Logika (Prencanaan secara logika)}

Untuk gambaran tentang aliran sistem yang diusulkan dapat dilihat dari Aliran Sistem Informasi (ASI) baru, hasil dari pengembangan system yang dilakukan. Dimana Anggota pustaka LOGIN dan mencari koleksi buku yang akan dipinjam dan menyerahkannya kepada petugas pustaka, kemudian petugas mengecek koleksi, kartu anggota, dan memberikan tanggal pengembalian buku, kemudian petugas menginputkan data kedalam database peminjaman buku, setelah itu petugas membuat laporan peminjaman buku dan menyerahkannya kepada kepala pustaka. Setelah petugas melakukan pengecekan peminjaman buku, maka petugas menyerahkan koleksi yang dipinjam kepada anggota perpustakaan. Adapun skema dari ASI Peminjaman Buku yang baru tersebut dapat dilihat pada tabel 1 berikut ini :
Tabel 1. Aliran Sistem Informasi (ASI) Peminjaman Buku yang baru

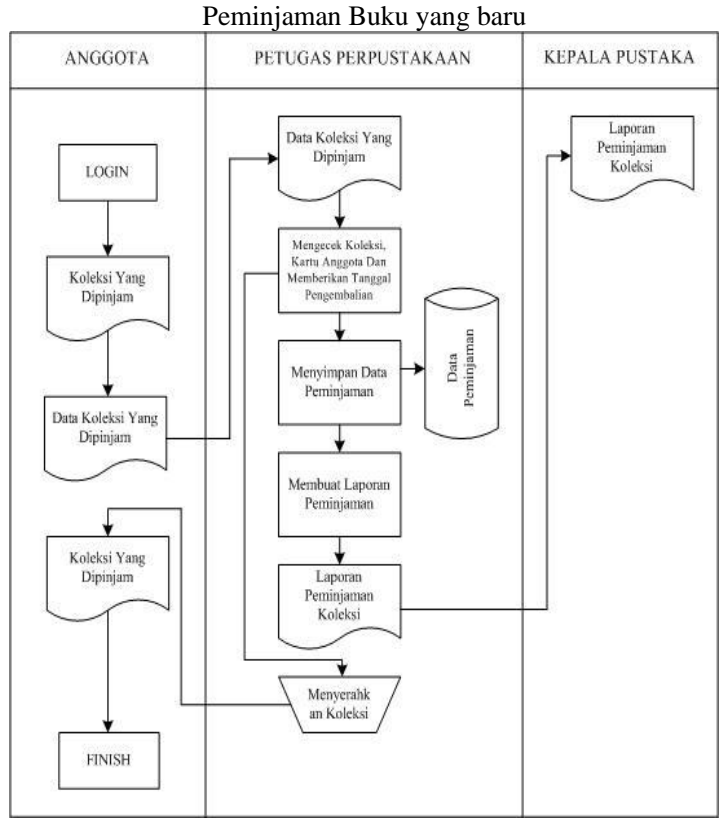

Anggota yang akan mengembalikan buku bisa langsung login, mengembalikan buku dan petugas akan mengecek apakah anggota terlambat atau tidak, jika anggota terlambat mengembalikan buku maka anggota harus membayar denda, jika anggota tidak terlambat mengembalikan buku maka anggota telah selesaikan melakukan proses pengembalian buku. Adapun skema dari ASI Pengembalian Buku yang baru tersebut dapat dilihat pada tabel 2 berikut ini :

Tabel 2. Aliran Sistem Informasi (ASI) Pengembalian Buku yang baru

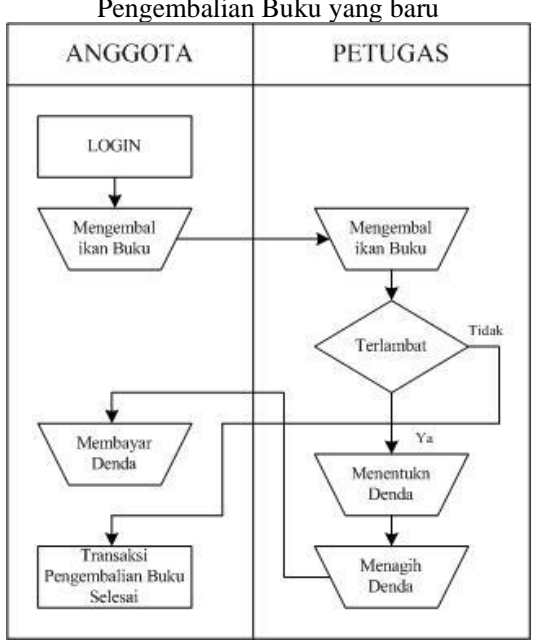

\subsection{Perancangan Sistem}

\section{Context Diagram :}

Diagram konteks merupakan salah satu alat bantu dalam melakukan analisis terstruktur dan menganalisan sistem yang akan dikembangkan. Diagram konteks ini menggambarkan suatu sistem secara garis besarnya atau keseluruhannya saja. Dalam Diagram konteks juga digambarkan entitas eksternal yang 
merupakan perangkat pikir yang menghasilkan data yang akan diolah oleh sistem maupun tujuan dari informasi yang dihasilkan oleh sistem. Adapun diagram konteks yang diusulkan. Pada gambar 2 Conteks diagram dapat dijelaskan bahwa didalam aliran conteks diagram terdapat dua buah entity yang terdiri dari anggota perpustakaan dan petugas perpustakaan. Adapun prosesnya dimulai dari memasukan data buku, data pinjam buku, data pengembalian buku kedalam sistem informasi perpustakaan, dari hasil pengolahan sistem tersebut masing-masing entity mendapatkan sebuah laporan tentang peminjaman dan pengembalian buku perpustakaan.

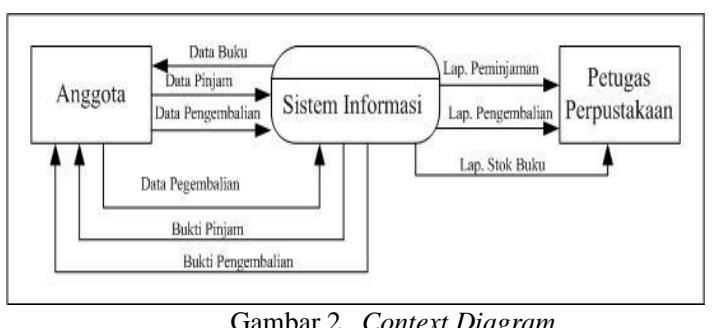

\section{Data Flow Diagram (DFD)}

DFD adalah gambaran sistem secara logika, gambaran ini tidak tergantung pada perangkat keras, perangkat lunak, struktur data atau organisasi file. Keuntungan menggunakan DFD adalah untuk memudahkan pemakai yang kurang menguasai bidang komputer untuk mengerti sistem yang akan dikembangkan. Untuk lebih rincinya dalam menggambarkan sistem informasi peminjaman dan pengembalian buku pada perpustakaaan Nagari Saning Bakar dapat dilihat pada gambar 3 dimana Anggota melakukan login, menginputkan data peminjaman buku dan pengembalian buku, petugas pustaka memberikan output buku, output peminjaman buku, output pengembalian buku, dan laporan stok buku.

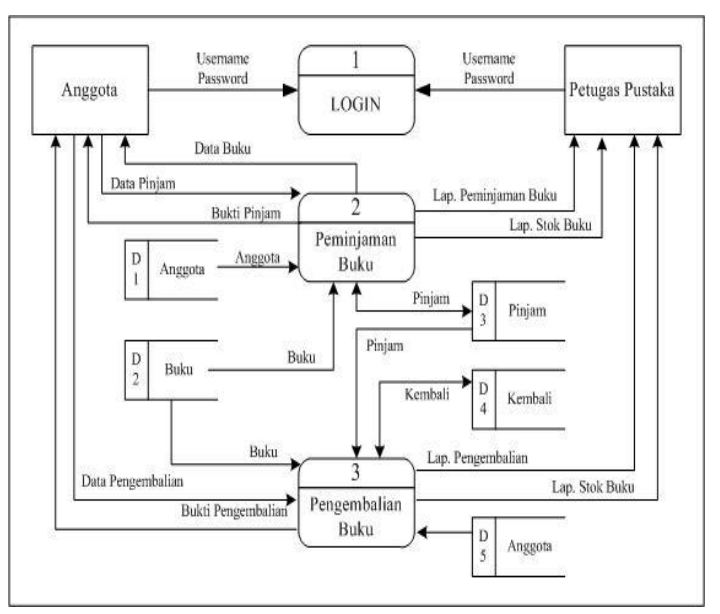

Gambar 3. Data Flow Diagram

\section{Desain Program}

Program yang dibuat dalam meimplementasikan sistem informasi pembayaran rekening air ini adalah program berbasis web Berikut ini adalah rancangan yang telah dibuat :

a. Desain Form login

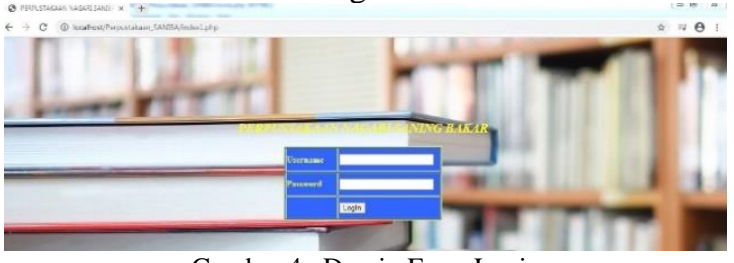

Gambar 4. Desain Form Login

b. Desain Form Home

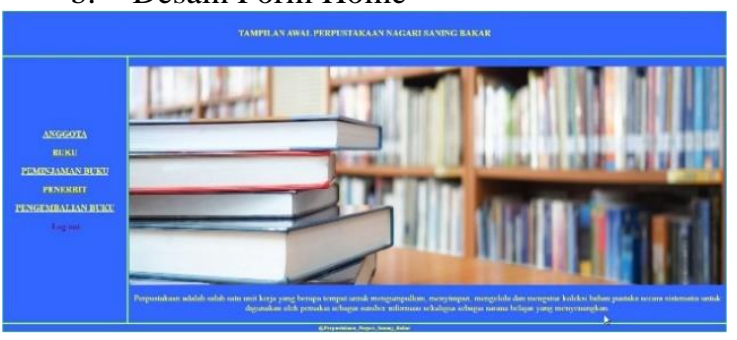

Gambar 5. Desain Form Home

c. Desain Data Anggota

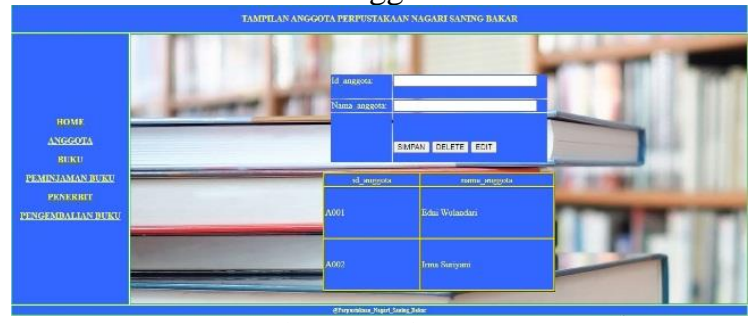

Gambar 6. Desain Data Anggota

d. Desain Data Buku

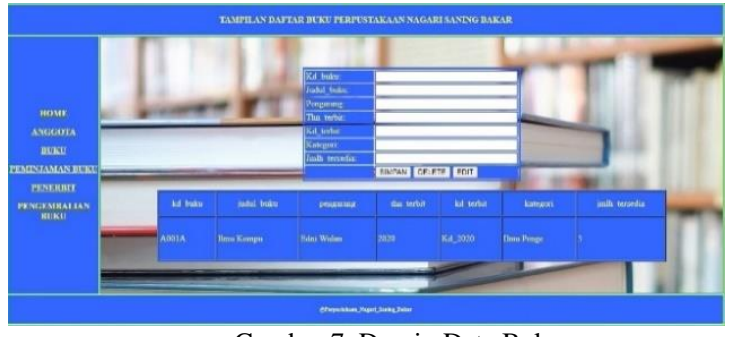

Gambar 7. Desain Data Buku

4. Desain Data Peminjaman Buku

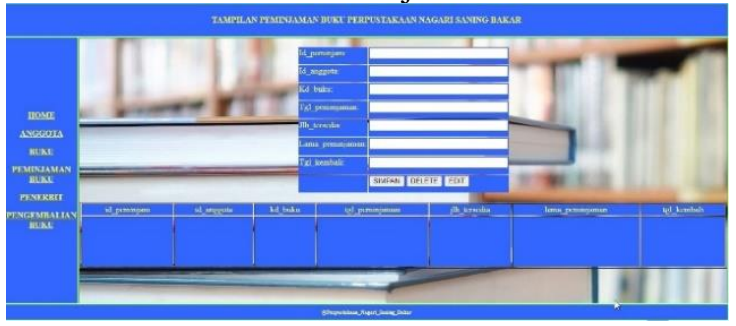

Gambar 8. Data Peminjaman Buku 
5. Desain Data Pengembalian Buku

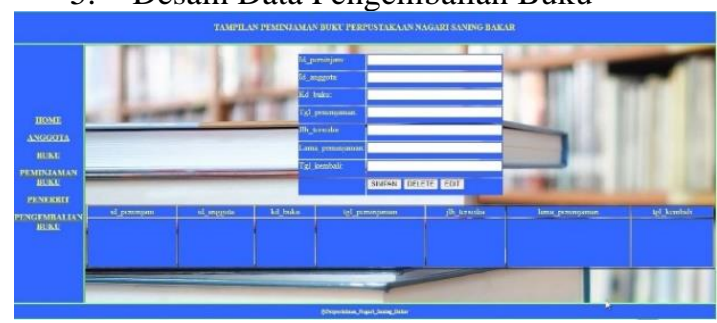

Gambar 9. Desain Form Input Data pembayaran

6. Desain Data Penerbit

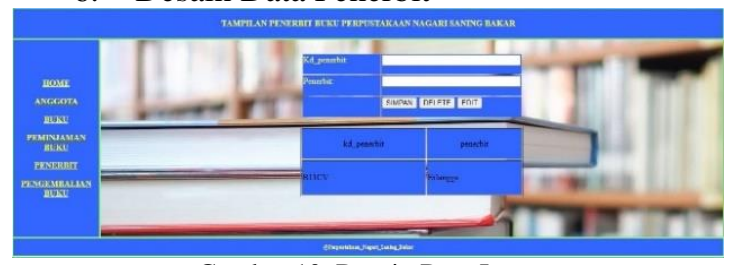

Gambar 10. Desain Data Input

\subsection{Pengujian Sistem}

1. Pengujian Fungsional :

Pengujian program dilakukan menggunakan pengujian fungsional untuk menguji fasilitas dan fungsi dari aplikasi yang dibuat. Test input dan output untuk fungsi yang ada tanpa memperhatikan prosesnya. Hasil dari pengujian secara fungsional menghasilkan hasil yang sesuai yang diharapkan. Semua fungsi yang direncanakan dan dirancang berjalan sesuai fungsinya.

2. Pengujian Praktikalitas dan Efektivitas Sitem:

Pengujian praktikalitas dan efektivitas dilakukan untuk melihat sejauh mana Praktikalitas dan Efektivitas sistem yang dibuat. Pengujian ini dilakukan dengan membandingkan Praktikalitas dan Efektivitas sistem yang lama dengan sitem yang baru dibuat.

\section{KESIMPULAN}

Berdasarkan analisa dan pembahasan pada bab sebelumnya maka penulis dapat menarik kesimpulan bahwa penerapan Sistem Informasi Peminjaman Dan Pengembalian Buku Pada Perpustakaan Nagari Saning Bakar berbasis web ini dapat membantu dalam peminjaman dan pengembalian buku yang lebih efektif, efesien, akurat dan mudah dalam penyajian laporan.

\section{DAFTAR PUSTAKA}

Agus Irawan dan Ahmad Najiullah.(2015). SISTEM INFORMASI PERPUSTAKAAN PADA UNIVERSITAS SERANG RAYA BERBASIS WEB. Jurnal PROTEKINFO Vol.2 September 2015

Andi Rahman Putera dan Malik Ibrahim.(2018). Rancang Bangun Sistem Informasi Peminjaman Dan Pengembalian Buku Perpustakaan SMP Negeri 1 Madiun. Journal of Computer And
Information Technology Vol.1, No.2, February 2018

Herman Adi Riyanto,dkk.(2016). Sistem Informasi Perpustakaan Umum Grati Kabupaten Pasuruan Berbasis Web Menggunakan Program Php Dan Database Mysql. JIMP - Jurnal Informatika Merdeka Pasuruan Vol.2, No.1 Agustus 2016

Khana Wijaya.(2019). Rancang Bangun Sistem Informasi Perpustakaan Menggunakan Java (Netbeans 7.3). Jurnal SISFOKOM, Volume 08, Nomor 01, Maret 2019

Yadi Utama.(2011). SISTEM INFORMASI BERBASIS WEB JURUSAN SISTEM INFORMASI FAKULTAS ILMU KOMPUTER UNIVERSITAS SRIWIJAYA. Jurnal Sistem Informasi (JSI), VOL. 3, NO. 2, Oktober 2011 